\title{
Management of struvite uroliths in dogs
}

\author{
Serena Calabrò ${ }^{1}$, Raffaella Tudisco ${ }^{1}$, Sergio Bianchi ${ }^{2}$, Micaela Grossi ${ }^{1}$, Antonio De Bonis ${ }^{3}$ \\ and Monica Isabella Cutrignelli ${ }^{1 *}$ \\ ${ }^{1}$ Department of Animal Science and Food Control, University of Napoli Federico II, Via Fedrico Delpino 1, \\ 80137 Napoli, Italy \\ ${ }^{2}$ Farmina Pet Food Italia, Via Nazionale delle Puglie, 80035 Nola (NA), Italy \\ ${ }^{3}$ Clinica Veterinaria Sannio, Via Fontanelle 12, 82100 Benevento, Italy
}

(Received 20 December 2010 - Revised 10 January 2011 - Accepted 28 January 2011)

\section{Abstract}

Urolithiasis is a common clinical problem in dogs. Struvite and calcium oxalate are the predominant mineral types in dog urolithiasis The aim of the present study was to compare the effect of two commercial dry foods formulated for the management of struvite urolithiasis with different anion-cation balance on urinary $\mathrm{pH}$. For the trial, twelve privately owned adult dogs showing struvite urolithiasis were studied. The dogs were randomly divided into two groups (A and B) and fed two dissolving diets for 3 months. The analyses of urine were repeated six times. In both diets, the anion-cation balance was negative ( -203 and -192 for diets A and B, respectively). At the first urine analysis, $\mathrm{pH}$ values of all the dogs were close to $8 \cdot 0$, and bacteria were present in about $70 \%$ of the samples and thus an antimicrobial was administered for 1 week. Both groups showed a progressive decrease in $\mathrm{pH}$ values, and after 2 months, in both cases, the recommended $\mathrm{pH}$ values for stone dissolution were achieved. From the sampling at $30 \mathrm{~d}$, group A showed $\mathrm{pH}$ values significantly $(P<0 \cdot 05)$ lower than group B, probably due to the lower anion-cation balance of diet A. The combination of antimicrobial and dietary therapy allowed the dissolution of struvite uroliths in both groups, even if the utilisation of the diet characterised by the lower anion-cation balance seems to decrease the urinary $\mathrm{pH}$ more rapidly. In this case, it seems necessary to interrupt the dietary treatment in order to avoid the risk of other diseases.

\section{Key words: Urolithiasis: Struvite: Dogs: Anion-cation balance}

Urolithiasis is a common clinical problem in dogs. Several risk factors for urolith formation, such as breed, sex, age, diet composition, water intake, infection of the urinary tract, environment and drug administration, have been recognised $^{(1)}$. Struvite and calcium oxalate are the predominant mineral types in urolithiasis in dogs, representing, overall, more than $80 \%$ of total reported urolithiasis cases ${ }^{(2,3)}$.

The aim of the present study was to compare the effect of two different dry foods for the management of struvite urolithiasis with different anion-cation balance on urinary $\mathrm{pH}$.

\section{Materials and methods}

A total of twelve privately owned adult dogs (4.3 (SEM 1.2) years old; live weight $20 \cdot 2$ (SEM 10$) \mathrm{kg}$ ) of different breeds showing struvite urolithiasis, confirmed by urolith composition assay, were divided into two groups (A and B), and fed for 3 months one of two dry diets (Hill's prescription diet $\mathrm{c} / \mathrm{d}$ named $\mathrm{A} v$. an experimental diet named $\mathrm{B}$ ) formulated in order to dissolve struvite uroliths. After the first evaluation (time 0), all the dogs were returned to their owner, and the following recommendations were specifically indicated: (1) increase the water administration in order to dilute the urine; (2) increase the outdoor time in order to promote the voluntary urination. The diets were analysed for chemical and mineral composition ${ }^{(4,5)}$, and the anioncation balance $(\mathrm{mEq} / \mathrm{kg} \mathrm{DM})$ was calculated according to the equation proposed by Langendorf ${ }^{(6)}$ :

$$
\begin{aligned}
& 49.9 \times \mathrm{Ca}+82.3 \times \mathrm{Mg}+43.5 \times \mathrm{Na}+25.6 \times \mathrm{K}-64.6 \\
& \times \mathrm{P}-62.4 \times \mathrm{S}-28.2 \times \mathrm{Cl} .
\end{aligned}
$$

Urine analyses were repeated six times (every 15d). Urine was collected in the morning immediately after the food administration.

All procedures were approved by the Federico II Ethics Committee.

Data were processed using PROC GLM of Statistical Analysis Systems (SAS Institute, Cary, NC, USA) ${ }^{(7)}$. 
Table 1. Chemical and mineral composition of the diets

\begin{tabular}{|c|c|c|}
\hline Diets & $A^{*}$ & $\mathrm{~B}^{*}$ \\
\hline $\mathrm{CP}(\%)$ & $21 \cdot 7$ & 19.5 \\
\hline EE (\%) & 19.6 & $19 \cdot 0$ \\
\hline CF $(\%)$ & $2 \cdot 70$ & 1.50 \\
\hline Ash (\%) & $4 \cdot 30$ & 4.40 \\
\hline $\mathrm{Ca}(\mathrm{g} / \mathrm{kg} \mathrm{DM})$ & $7 \cdot 88$ & $6 \cdot 20$ \\
\hline $\mathrm{Mg}(\mathrm{g} / \mathrm{kg} \mathrm{DM})$ & $1 \cdot 12$ & 1.40 \\
\hline $\mathrm{Na}(\mathrm{g} / \mathrm{kg} \mathrm{DM})$ & 3.67 & 3.35 \\
\hline $\mathrm{K}(\mathrm{g} / \mathrm{kg} \mathrm{DM})$ & $7 \cdot 50$ & 7.93 \\
\hline 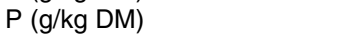 & $9 \cdot 61$ & 8.63 \\
\hline $\mathrm{S}(\mathrm{g} / \mathrm{kg} \mathrm{DM})$ & $5 \cdot 76$ & 5.43 \\
\hline $\mathrm{Cl}(\mathrm{g} / \mathrm{kg} \mathrm{DM})$ & 7.50 & 7.51 \\
\hline Anion-cation (mEg/kg DM) & -203 & -192 \\
\hline
\end{tabular}

$\mathrm{CP}$, crude protein; $\mathrm{EE}$, diethyl ether extract; $\mathrm{CF}$, crude fibre.

${ }^{*}$ Hill's prescription diet $c / d$ named $A v$. an experimental diet named B.

† Anion-cation balance calculated on the basis of food content in $\mathrm{g} / \mathrm{kg} \mathrm{DM}: \mathrm{mEq} / \mathrm{kg} \mathrm{DM}=49.9 \times \mathrm{Ca}+82.3 \times \mathrm{Mg}+43.5$ $\times \mathrm{Na}+25.6 \times \mathrm{K}-64.6 \times \mathrm{P}-62.4 \times \mathrm{S}-28.2 \times \mathrm{Cl}$.

Table 2. Mean values of urinary $\mathrm{pH}$ and density $\left(\mathrm{kg} / \mathrm{m}^{3}\right)$ registered for groups $\mathrm{A}(n 6)$ and $\mathrm{B}(n 6)$ (Mean values with their standard errors)

\begin{tabular}{|c|c|c|c|c|c|c|c|c|}
\hline \multirow[b]{3}{*}{ Sampling day } & \multicolumn{4}{|c|}{$\mathrm{pH}$} & \multicolumn{4}{|c|}{ Density } \\
\hline & \multicolumn{2}{|c|}{ Group A } & \multicolumn{2}{|c|}{ Group B } & \multicolumn{2}{|c|}{ Group A } & \multicolumn{2}{|c|}{ Group B } \\
\hline & Mean & SEM & Mean & SEM & Mean & SEM & Mean & SEM \\
\hline 0 & 8.0 & 0.5 & $8 \cdot 0$ & 0.8 & 1043 & $12 \cdot 5$ & 1045 & $13 \cdot 3$ \\
\hline 15 & $6 \cdot 7$ & 0.7 & 6.9 & 0.9 & 1044 & $10 \cdot 4$ & 1045 & $11 \cdot 2$ \\
\hline 30 & $6 \cdot 3^{b}$ & 0.5 & $6 \cdot 6^{\mathrm{a}}$ & 0.4 & 1040 & $11 \cdot 8$ & 1042 & $10 \cdot 3$ \\
\hline 45 & $5 \cdot 8^{\mathrm{b}}$ & 0.4 & $6 \cdot 1^{\mathrm{a}}$ & 0.4 & 1025 & 9.45 & 1031 & $12 \cdot 1$ \\
\hline 60 & $5 \cdot 7^{b}$ & 0.5 & $6 \cdot 0^{\mathrm{a}}$ & 0.3 & 1020 & 1.3 & 1022 & $10 \cdot 1$ \\
\hline 75 & $5 \cdot 6^{\mathrm{b}}$ & 0.5 & $5 \cdot 9^{\mathrm{a}}$ & 0.5 & 1015 & $12 \cdot 4$ & 1023 & 12.5 \\
\hline
\end{tabular}

${ }^{\mathrm{a}, \mathrm{b}}$ Mean values within a row with unlike superscript letters were significantly different for diets $\mathrm{A}$ and $\mathrm{B}(P<0 \cdot 05)$.

\section{Results}

The chemical and mineral composition of the diets is reported in Table 1. The chemical and mineral composition of both diets was appropriate for dissolving struvite uroliths ${ }^{(8,9)}$. In particular, the diets were characterised by moderate protein amounts in order to reduce urinary urea availability for ureaseproducing bacteria. The fibre contents were lower than in maintenance diets in order to improve the digestibility and to reduce water losses via faeces. Regarding mineral composition, both diets were characterised by low Mg and P supplementation. Although in both diets the anion-cation balance was negative, diet A showed an anion-cation balance lower than diet B. This was due to the differences in the amount of $\mathrm{P}, \mathrm{S}$ and $\mathrm{Mg}$.

The mean values of urinary $\mathrm{pH}$ and density registered during the trial are reported in Table 2. For urine analysed at the first time point, the mean $\mathrm{pH}$ values were 8.0 (SEM 0.5 ) and 8.0 (SEm 0.8 ) for groups A and B, respectively, and bacteria were found in about $70 \%$ of the samples. For this reason, an antimicrobial (fluoroquinolones in tablet form) was given for 1 week. All urine samples analysed after $15 \mathrm{~d}$ did not show bacteria.

Both groups showed a progressive decrease in $\mathrm{pH}$ values. This could be affected to the chosen measuring time (each $15 \mathrm{~d}$ in the morning immediately after the food administration), instead individual urine $\mathrm{pH}$ changes during the day ${ }^{(10)}$. From the $30 \mathrm{~d}$ sampling, dogs fed diet A showed $\mathrm{pH}$ values significantly $(P<0.05)$ lower than dogs fed diet B. This could be due to the lower anion-cation balance of diet A. After $45 \mathrm{~d}$ of therapy, in both cases, the $\mathrm{pH}$ values recommended for stone dissolution were on average $5 \cdot 9-6 \cdot 1^{(1)}$. From $45 \mathrm{~d}$ sampling, group A showed $\mathrm{pH}$ values lower than 5.9. The $\mathrm{pH}$ values, registered after $75 \mathrm{~d}$ of dietary treatment, indicated the necessity to change the diet in both cases in order to avoid the risk of other diseases (e.g. urate urolithiasis $\left.{ }^{(1)}\right)$. At the end of the trial, none of the urine samples showed crystals as has been reported in other studies ${ }^{(11,12)}$.

\section{Conclusion}

The combination of antimicrobial and dietary therapy allowed the dissolution of struvite uroliths in both groups, even if the utilisation of the diet characterised by the lower anion-cation balance seems to reduce the urinary $\mathrm{pH}$ more rapidly.

\section{Acknowledgements}

The authors' contributions were as follows: S. C. and R. T. performed the chemical and mineral analysis of the diets. S. B. and M. I. C. chose the diets and calculated the individual 
ratios. S. C. were involved in the statistical analysis. A. D. B. and M. G. performed the diagnoses and urine analysis. M. I. C. prepared the experimental design. In any case, all the authors were equally involved in the interpretation of the results and manuscript preparation. The present study was supported by the Italian Ministry of Education, University and Research (individual research funding M. I. C.).

\section{References}

1. Stevenson A \& Rutgers C (2006) Nutritional management of canine urolithiasis. In Encyclopaedia of Canine Clinical Nutrition, pp. 285-315 [P Pibot, V Biourge and D Elliott, editors]. Aimargues: Aniwa SAS.

2. Osborne CA, Lulich JP, Polzin DJ, et al. (1999) Analysis of 77,000 canine uroliths. Perspectives from the Minnesota Urolith Center. Vet Clin North Am Small Anim Pract 29, 17-35.

3. Picavet P, Detilleux J, Verschuren S, et al. (2007) Analysis of 4495 canine and feline uroliths in the Benelux. A retrospective study: 1994-2004. J Anim Physiol Anim Nutr (Berl) 91, $247-251$.

4. AOAC (2006) Official Methods of Analysis. Arlington, VA: Association of Official Analytical Chemists.

5. de Ruig WG (1986) Atomic Absorption Spectrometric determination of calcium, copper, iron, magnesium, manganese, potassium, sodium and zinc in animal feeding stuffs: interlaboratory collaborative studies. I Assoc Off Anal Chem 69, 1009-1013.

6. Langendorf H (1963) Säure-Basen-Gleichgewicht und chronische acidogene und alkalogene Ernährung (Acid-base balance and chronic acidogenic and alkalogene nutrition). In Zeitschrift für Ernährungswissenschaft (Journal of Nutrition Science), pp. 1-76 [K Lang, editor]. Mainz.

7. SAS (2000) User's Guide Statistics version 8.2. Cary, NC: SAS Institute, Inc.

8. Lulich JP, Osborne CA, Bartges JW, et al. (2000) Canine lower urinary tract disorders. In Textbook of Veterinary Internal Medicine - Diseases of the Dog and Cat, 5th ed., pp. 1747-1781 [SJ Ettinger and EC Feldman, editors]. Philadelphia, PA: WB Saunders Company.

9. Commission Directive 2008/38/EC of 5 March 2008 . Establishing a list of intended uses of animal feedingstuffs for particular nutritional purposes. EN - 20.08.2008.

10. Kienzle E \& Wilms-Eilers S (1994) Struvite diet in cats: effect of ammonium chloride and carbonates on acid base balance of cats. J Nutr 124, 2652S-2659S.

11. Osborne CA, Lulich JP, Polzin DJ, et al. (1999) Medical dissolution and prevention of canine struvite urolithiasis. Vet Clin North Am Small Anim Pract 29, 17-38.

12. Rinkardt NE \& Houston DM (2004) Dissolution of infectioninduced struvite bladder stones using a non-calculolytic diet and antibiotic therapy. Can Vet J 45, 838-840. 